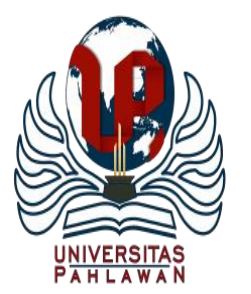

Jurnal Abdidas Volume 1 Nomor 5 Tahun 2020 Halaman 442 - 449

JURNAL ABDIDAS

Community Development Service on Educational and Health Sciences

http://abdidas.org/index.php/abdidas

\title{
Pengembangan Ekowisata dalam Upaya Pemberdayaan Masyarakat Lokal di Desa Maitara Tengah Kecamatan Tidore Utara
}

\author{
Yetty $^{1}$, Rheza Pratama ${ }^{2}$, Johan Fahri ${ }^{3}$ \\ Universitas Khairun, Maluku Utara, Indonesia ${ }^{1,2,3}$ \\ E-mail : y.tarumadoja@gmail.com ${ }^{1}$ rhezapratama@unkhair.ac.id ${ }^{2}$ johan.fahri@unkhair.ac.id ${ }^{3}$
}

\begin{abstract}
Abstrak
Desa Maitara tengah letak geografisnya sangat strategis karena terletak diantara dua kota yang produktif di Provinsi Maluku Utara, yaitu Kota Tidore dan Kota Ternate. Dalam pelaksanaan Program Kemitraan Masyarakat (PKM) ini, program/kegiatan yang dilaksanakan untuk memecahkan permasalahan adalah memberikan pelatihan kepada masyarakat tentang potensi ekowisata dan pentingnya mempunyai usaha oleholeh khas Desa Maitara untuk meningkatkan pendapatan masyarakat dalam sebuah kemasan produk ekowisata. Kegiatan ini dilakukan dengan cara memberikan sosialisasi dan pelatihan yang meliputi ceramah, diskusi dan praktik/simulasi pembuatan oleh-oleh. Adapun sasaran yang dilibatkan dalam kegiatan PKM ini adalah aparat Desa Maitara Tengah dan masyarakat Desa Maitara pada umumnya. Pelaksanaan kegiatan PKM yang dilaksanakan di Desa Maitara Tengah sudah berjalan sesuai dengan rencana awal, tetapi dalam proses pelaksanaannya masih perlu dilakukan secara regular dalam memastikan kesiapan Desa Maitara sebagai desa wisata yang mandiri. Hal ini akan bermanfaat dalam pengembangan ekowisata di Pulau Maitara pada umumnya. Untuk itulah, tentu pengabdian dalam hal pelatihan pengemasan ekowisata dan pembuatan oleh-oleh khas Maitara hendaknya dilanjutkan secara berkelanjutan.
\end{abstract}

Kata kunci: pemberdayaan masyarakat, pengembangan ekowisata, oleh-oleh khas Maitara

\begin{abstract}
Maitara Village is geographically very strategic because it is located between two productive cities in North Maluku Province, namely Tidore City and Ternate City. In implementing this Community Partnership Program (PKM), the programs / activities carried out to solve problems are: Providing training to the community about the potential of Ecotourism and the importance of having a typical souvenir business in Maiatara Village to increase community income in an ecotourism product package. This activity is carried out by providing socialization and training which includes: Lectures, discussions and practice / simulation of making souvenirs. The targets involved in this PKM activity were the officials of Maitara Tengah Village and the Maitara Village Community in general. The implementation of PKM activities carried out in Maitara Tengah Village has been going according to the initial plan, but in the implementation process it still needs to be carried out regularly in ensuring the readiness of Maitara Village as an independent tourism village. This will be useful in developing ecotourism in Maitara Island in general. For this reason, of course dedication in terms of ecotourism packaging training and making typical Maitara souvenirs should be continued in a sustainable manner.
\end{abstract}

Keywords: community development, ecotourism development, Maitara souvenirs

Copyright (c) 2020 Yetty, Rheza Pratama, Johan Fahri

$\triangle$ Corresponding author

Address : Kota Ternate

Email : rhezapratama@unkhair.ac.id

ISSN 2721-9224 (Media Cetak)

Phone : 085240596552

ISSN 2721-9216 (Media Online)

DOI : https://doi.org/10.31004/abdidas.v1i5.98 
DOI : https://doi.org/10.31004/abdidas.v1i5.98

\section{PENDAHULUAN}

Ekowisata merupakan sejenis pariwisata yang berwawasan lingkungan (Haerani, 2012). Maksudnya, melalui aktivitas yang berkaitan dengan alam, wisatawan diajak melihat alam dari dekat, menikmati keaslian alam dan lingkungannya sehingga membuatnya tergugah untuk mencintai alam. Semuanya ini sering disebut dengan istilah back-to-nature. Berbeda dengan pariwisata yang biasa kita kenal, ekowisata dalam penyelenggaraannya tidak menuntut tersedianya fasilitas akomodasi yang modern atau glamour yang dilengkapi dengan peralatan yang serba mewah atau bangunan artifisial yang berlebihan.

Ekowisata juga akan menyerap tenaga kerja, meningkatkan taraf hidup masyarakat, meningkatkan produk daerah ke ajang internasional, dan lain sebagainya. Sementara saat ini wisatawan lebih tertarik dengan ekowisata yang menyuguhkan alam pedesaan. Dari situlah kemudian muncul dan berkembang konsep ekowisata yang disebut dengan desa wisata. Desa wisata merupakan sebuah kawasan pedesaan yang memiliki keunikan dan karakteristik khusus untuk menjadi destinasi wisata, antara lain lingkungan bernuansa alami, tradisi dan budaya masih dipegang masyarakat, makanan khas, sistem pertanian, dan sistem kekerabatan (Marpaung, 2002).

Provinsi Maluku Utara memiliki segudang potensi pariwisata. Wisata budaya, purbakala, sejarah, ada istiadat, kawasan suaka alam serta wisata bahari berupa pulau dan pantai yang indah dengan taman laut serta jenis ikan hias terdapat di kepulauan yang letaknya di sebelah Timur Pulau
Sulawesi ini. Salah satu pulau yang menawarkan panorama indah adalah Pulau Maitara yang memiliki luas 206 hektar. Pulau Maitara berada di antara Pulau tidore dan Pulau ternate lebih tepatnya di Kota Tidore, Propinsi Maluku Utara.

Pulau Maitara merupakan salah satu kawasan wisata di Kota Tidore Kepulauan Provinsi Maluku Utara yang terletak diantara Pulau Tidore dan selatan Pulau Ternate adalah suatu bongkahan pulau kecil yang alamiah berpenduduk 1900 jiwa (2017) dengan keramahtamahan, budaya dan jiwa sosialnya yang tinggi serta menyimpan kekayaan yang potensial untuk pengembangan sebagai kawasan wisata. Potensi dimiliki diantaranya keindahan panorama gunung, kawasan alam, serta pantai, panorama alam yang indah serta hamparan pasir puth disepanjang pantai, memiliki air laut yang jernih, dihiasi oleh Gunung Gamalama (Gunung Kota Ternate) dan Gunung Kie Matubu (Gunung Kota Tidore Kepulauan) yang terletak didepan Pulau Maitara.

Sebagai salah satu kawasan wisata di Kecamatan Tidore Utara, Desa Maitara tengah (Pulau Maitara) berpotensi dimanfaatkan sebagai pengembangan kawasan ekowisata yang dapat mengimbangi dampak yang terjadi akibat dari perencanaan pariwisata konvensional dengan tatanan budaya pada wilayah Maluku Utara sehingga memberikan dampak yang kecil terhadap pergeseran nilai-nilai budaya, penyimpangan dan perilaku masyarakat pada wilayah selain itu perencanaan ekowisata membuka peluang dan kesempatan serta keterlibatan dari masyarakat dalam mengembangkan kawasan tersebut, selain 
itu juga dalam pengembangan kawasan ekowisata di Pulau Maitara dilakukan sesuai dengan potensi dan keunggulan yang dimiliki oleh Pulau Maitara itu sendiri (Haerani, 2012).

Potensi-potensi tersebut belum didukung sepenuhnya ketersediaan sarana dan prasarana pariwisata yang memadai untuk pengembangan wisata Pulau Maitara itu sendiri, sehingga untuk saat ini Pulau Maitara belum mampu dimanfaatkan sebagai salah satu kawasan ekowisata yang dapat meningkatkan pendapatan daerah baik untuk Kota Tidore Kepulauan maupun Provinsi Maluku Utara.

Pengembangan kawasan desa wisata di Pulau Maitara selain memberikan peluang bagi penduduk setempat, juga memberikan konstribusi disektor perekonomian dalam hal peningkatan PAD baik untuk Pemerintah Kota Tidore Kepulauan maupun Pemerintah Provinsi Maluku Utara serta dapat memberikan lapangan kerja baru bagi masyarakat yang ada di Kota Tidore Kepulauan umumnya.

Pengembangan ekowisata di Pulau Maitara ini masih mengalami permasalahan seperti kurangnya variasi kegiatan wisata dan fasilitas penunjang wisata seperti kemudahan akses untuk menuju lokasi wisata, hal tersebut menyebabkan rendahnya minat wisatawan untuk berkunjung (Hanafi, 2011). Berdasarkan analisis situasi dilingkungan mitra maka dalam dirumuskan permasalahan antara lain:

1. Strategi pengembangan apa yang sebaiknya diprioritaskan dalam pengelolaan ekowisata di Pulau Maitara Tengah?

2. Manfaat apa saja yang diperoleh untuk pemberdayaan masyarakat dalam pengembangan ekowisata di Pulau Maitara Tengah?

Oleh karena itu, program pengabdian masyarakat dengan didukung kompetensi bidang Ilmu Ekonomi, manajemen pemasaran dan manajemen sumber daya manusia serta keuangan.

\section{METODE}

Pemecahan permasalahan program PKM tentang pengembangan ekowisata di Desa Maitara Tengah dilakukan dengan beberapa pendekatan yang dilakukan secara bersama-sama yaitu :

1) Pertama

Berbasis kelompok ibu/bapak kelompok usaha, seluruh kegiatan pengabdian masyarakat dilakukan kepada masyarakat dengan menggunakan kelompok sebagai media belajar dan pendampingan, perencanaan dan memonitor dan evaluasi seluruh kegiatan pengabdian masyarakat.

2) Kedua

Tahap kedua merupakan pelaksanaan kegiatan komprehensif, seluruh kegiatan pengabdian masyarakat dilakukan secara serentak terkait dengan SDM, peluang usaha dan potensi wisata, serta pemasaran yang dilakukan melalui pelatihan dan pendampingan tenaga usaha (Pratama, 2019).

3) Ketiga

Pada tahap ketiga metode yang digunakan berbasis potensi ekonomi lokal dan kearifan lokal dengan pengembangan sikap dan budaya lokal sehingga dapat menjadi produk unggulan yang memiliki ciri khas produk di Desa Maitara Tengah. Desa Maitara Tengah 
mempunyai potensi wisata yang luar biasa. Sirup dan Sambel berbahan dasar pala yang menjadi target tim dalam proses pelatihan pembuatan cendramata/ oleh-oleh.

Selanjutnya ketiga metode di atas diimlementasikan dalam 4 ( empat ) tahapan yaitu (1) sosialisasi, (2) peningkatan kompetensi, (3) produksi atau pelaksanaan kegiatan serta (4) monitoring dan evaluasi.

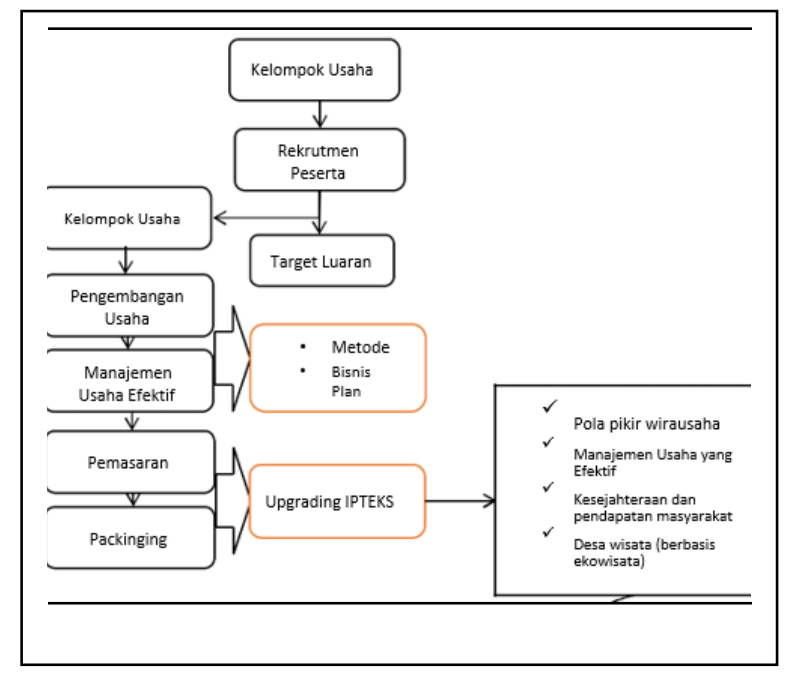

Gambar 1. Metode Pelaksanaan PKM

Pelaksanaan kegiatan PKM ini berlangsung 2 hari dari tanggal 11 Juli sampai dengan 12 Juli 2020 jam 08.00 WIT pagi sampai dengan selesai, dengan dihadiri 30 orang peserta (masyarakat Maitara Tengah). Kegiatan ini dilaksanakan di aula Kantor Desa Maitara Tengah. Pelaksanaan kegiatan ini juga menggunakan protokol kesehatan karena adanya wabah COVID-19.

\section{HASIL DAN PEMBAHASAN}

$$
\text { Pelaksanaan Program Kemitraan }
$$

Masyarakat (PKM) ini bertujuan untuk melengkapi wawasan pengetahuan dan keterampilan tentang pengembangan ekonomi dalam pengelolaan ekowisata dan ekowisata bagi pengembangan masyarakat di Pulau Maitara, perlu dilakukan inisiasi mulai dari kelompok-kelompok ekonomi kecil yang tidak produktif yang berada di Desa Maitara Tengah. Kegiatan pengabdian ini akan fokus pada 2 sub kegiatan pelatihan dan pendampingan, yaitu pelatihan pengembangan usaha dan pelatihan pengelolaan ekowisata.

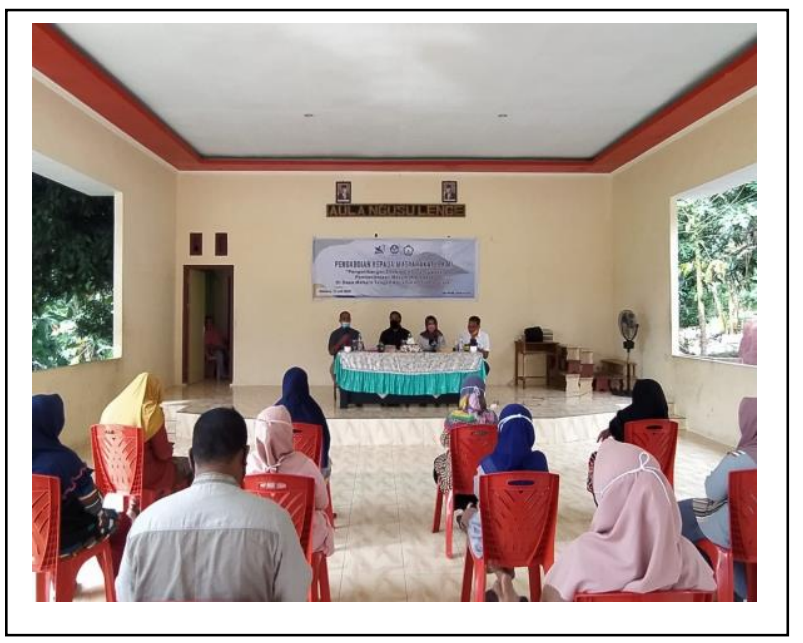

Gambar 2. Pelaksanaan PKM

Output yang didapat dari kegiatan Program Kemitraan Masyarakat (PKM) ini diantaranya adalah:

1 Masyarakat Maitara Tengah (Kelompok Mitra) diberikan pengetahuan dan informasi terkait potensi ekowisata, analisis peningkatan usaha (ekonomi produktif, pembekalan pembuatan oleh-oleh khas Desa Maitara Tengah. Karena oleh-oleh bukan sekadar buah tangan bagi keluarga atau kerabat. Industri oleh-oleh sanggup memberi manfaat ekonomi bagi pelaku, bahkan berkontribusi bagi sektor ekowisata di Desa Maitara Tengah. Jadi ketika kita dapat mengembangkan potensi industri 
oleh-oleh di Maitara, maka sektor ekowisata tersebut pun akan berkembang, dan kontribusi terhadap perekonomian di desa semakin besar. Peningkatan ekonomi masyarakat di lain pihak akan semakin mendorong kemampuan masyarakat untuk melakukan perjalanan wisata dan berbelanja oleh-oleh khas desa maitara.

2 Dari hasil pelaksanaan kegiatan PKM, mitra dalam hal ini adalah masyarakat desa Maitara Tengah (Kelompok Usaha) memahami mengenai isi materi. Materi tentang ekowisata dan potensi analisis usaha baru (oleh-oleh khas Maitara). Ekowisata juga dapat dilihat dari sisi ekonomi, khususnya bagi peningkatan perekonomian masyarakat setempat. Dari sisi ekonomi, ekowisata menciptakan lapangan pekerjaan di wilayah terpencil dan belum berkembang. Penekanan ekowisata pada sumber daya lokal dan peluang kerja menjadikan ekowista sebagai peluang bagi daerah yang sedang berkembang dan mempunyai potensi alam yang tinggi.

\section{Dampak Pelaksanaan PKM}

Penerapan konsep ekowisata juga dapat dilihat dari sisi ekonomi, khususnya bagi peningkatan perekonomian masyarakat Desa Maitara Tengah. Dari sisi ekonomi, ekowisata menciptakan lapangan pekerjaan di wilayah terpencil dan belum berkembang. Penekanan ekowisata pada sumber daya lokal dan peluang kerja menjadikan ekowista sebagai peluang bagi Desa Maitara Tengah yang sedang berkembang dan mempunyai potensi alam yang tinggi (Pratama, 2018).

Outcome yang didapat dari kegiatan Program Kemitraan Masyarakat (PKM) ini diantaranya adalah:

1 Dengan adanya program kemitraan masyarakat yang berupa sosialisasi dan pelatihan mengenai pengembangan ekowisata dan analisis potensi usaha, diharapkan dapat meningkatkan dan mengembangkan pengetahuan dan informasi mitra dalam hal ekowisata dan optimalisasi peluang usaha masyarakat.

2 Meningkatkan hospitality berlandaskan visi desa berbasis ekowisata yang diturunkan melalui program-program pelatihan baik bagi kelompok sadar wisata maupun masyarakat umum. Tujuannya tamu yang berkunjung mendapatkan kesan menyenangkan dan tidak terlupakan. Keterampilan dan keramahan dalam menerima tamu/wisatawan yang berkunjung menjadi prasyarat penting bagi pengembangan desa wisata. Oleh karena itu pengelola wisata dan masyarakat setempat perlu mendapatkan pelatihan-pelatihan softskill tersebut.

3 Bagi desa, identifikasi pengembangan ekowisata akan menambah pendapatan asli desa, selain itu mampu mengakselerasi desa dalam rangka mencapai status desa wisata. Sebelum adanya pelatihan tim pelaksana tidak menemukan oleh-oleh khas dari Desa Maitara Tengah. Pengembangan ekowisata juga dapat dilihat dari sisi ekonomi, khususnya bagi peningkatan perekonomian masyarakat 
setempat. Dari sisi ekonomi, ekowisata menciptakan lapangan pekerjaan bagi masyarakat desa maitara tengah.

Dari hasil wawancara Tim Pelaksana dengan Kepala Desa Maitara Tengah terkait kunjungan wisatawan (Hal ini sebab data 2020 belum di-update), hasil wawancara sebagai berikut:

Terkait data kujungan wisatawan memang menurun diawal tahun 2020 apalagi kita saat ini sedang mengalami masa pandemi akibat virus corona, hal ini membuat akses desa untuk wisata kami tutup selama periode Maret sampai dengan Mei. Nah dibulan Juli kami buka kembali, dan Alhamdulilah dari periode juni sampai dengan akhir Juli 2020 tiap hari pasti ada saja yang berkunjung ke Desa Maitara. Puncak kunjungan biasanya pada hari Jumat, dan hari libur. Dengan adanya program yang dilaksanakan ini bisa membuka pikiran saya dan masyarakat bagaimana menjemput potensi yang ada saat ini, Ekowisata dan oleh-oleh khas maitara merupakan solusi demi meningkatkan kesejahteraan masyarakat. (Kapala Desa Maitara Tengah, Agustus 2020).

Dari hasil wawancara diatas dapat menunjukan bahwa program kerja sama PKM yang dilaksanakan oleh TIM PKM Unkhair dan pemerintah Desa Maitara Tengah memberikan dampak bagi kehidupan dari aspek pariwisata dan ekonomi untuk masyarakat Desa Maitara Tengah.

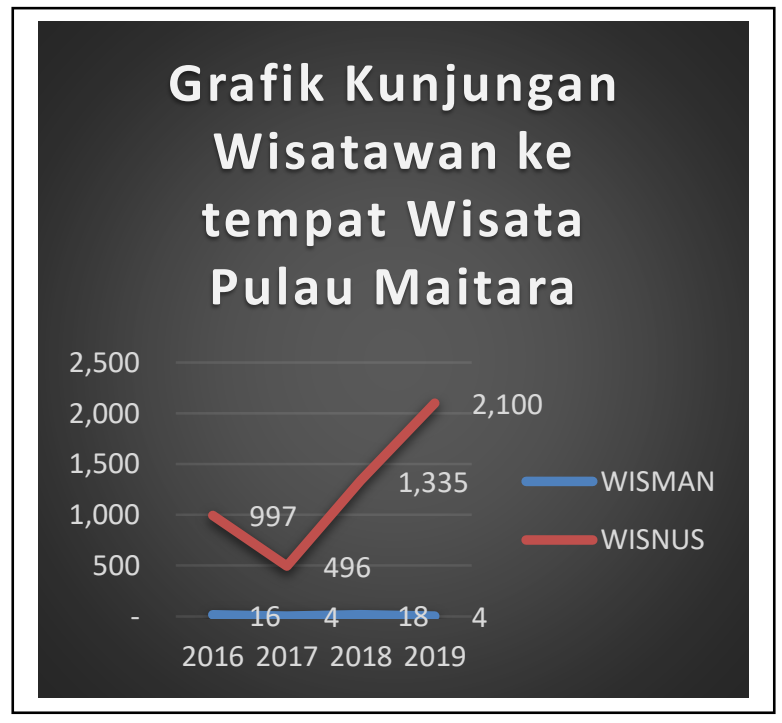

Gambar 3. Grafik Kunjungan Wisata

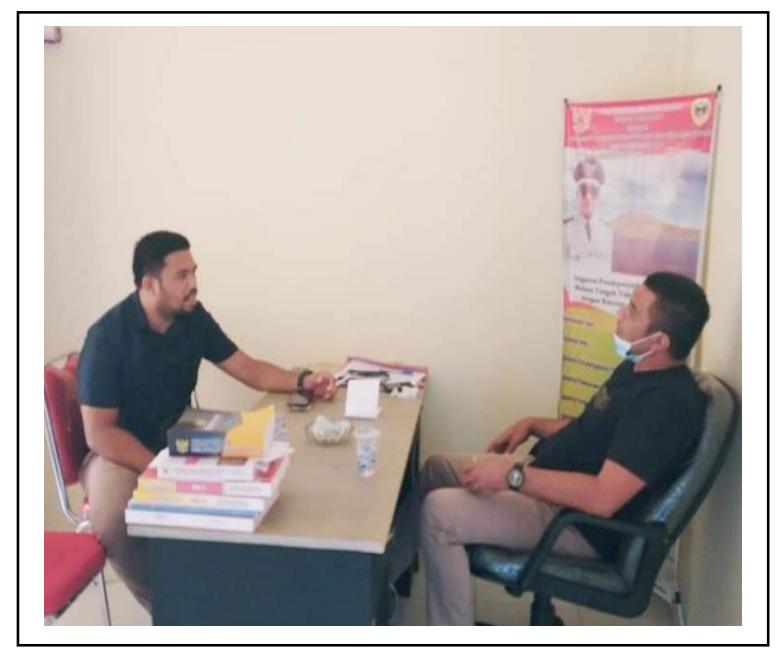

Gambar 4. Proses Wawancara dengan Kepala Desa

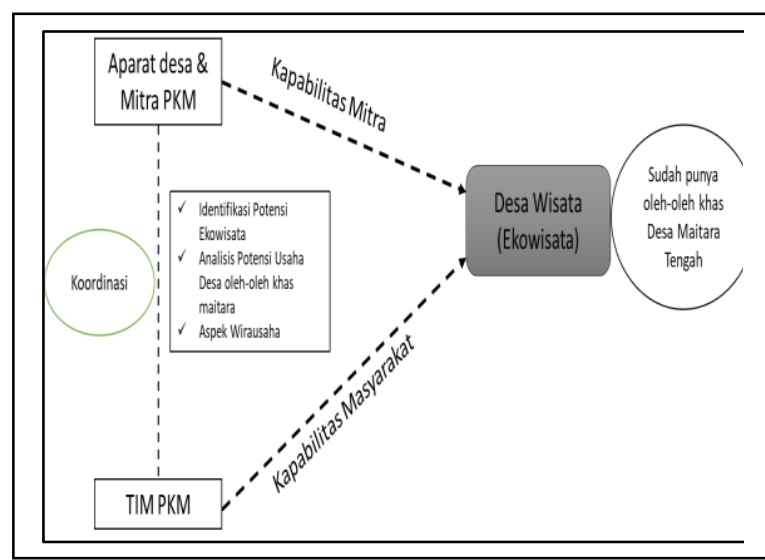

Gambar 5. Outcome yang diperoleh 
DOI : https://doi.org/10.31004/abdidas.v1i5.98

\section{SIMPULAN}

Kegiatan Program Kemitraan Masyarakat (PKM) ini berjalan dengan lancar karena materi yang disampaikan sangat menarik terlebih lagi kegiatan utama yang dijadwalkan yakni pengembangan ekowisata dan pembuatan oleholeh khas Maitara yang berbahan dasar buah pala disertai dengan praktik lapangan dan pendampingan oleh tim pelaksana PKM. Kegiatan PKM ini berjalan dengan baik dan para peserta pelatihan sangat antusias dalam mengikuti seluruh rangkaian acara yang diberikan. Adapun materi yang diberikan dalam pelaksanaan program PKM yaitu; pelatihan pengembangan ekowisata, analisis potensi usaha baru serta praktek pembuatan oleholeh khas Desa Maitara Tengah. Diakhir acara di tutup dengan program pendampingan, kegiatan pendampingan yang dimaksudkan untuk mengarahkan para mitra siap menjadikan Desa Maitara Tengah, menjadi desa wisata (berbasis ekowisata) dan berkelanjutan.

Disarankan agar adanya suatu sinergi yang baik antara pemerintah daerah, pemerintah desa, mapun mitra (masyarakat Desa Maitara Tengah) untuk selalu meningkatkan perannya di dalam mendukung pengembangan ekowisata dan oleholeh khas maitara tengah. Hal ini penting dilakukan untuk lebih menggembangkan potensi ekowisata Maitara Tengah di mata wisatawan lokal maupun manca negara. situasi pandemi di era kenormalan baru menuntut semua orang untuk menjalankan protokol kesehatan, industri pariwisata pun harus mengadopsi ketentuan itu dalam mengemas jasa layanan. Kebiasaan seperti menjaga jarak, menghindari kerumunan, selalu mengenakan masker, rajin mencuci tangan harus mampu dikemas sebagai bagian tidak terpisahkan dalam satu produk ekowisata di Desa Maitara Tengah.

\section{UCAPAN TERIMA KASIH}

Program Kemitraan Masyarakat tentang Pengembangan Ekowisata Dalam Upaya Pemberdayaan Masyarakat Lokal di Desa Maitara Tengah Kecamatan Tidore Utara, yang didanai oleh Rektorat Riset Pengabdian Masyarakat (DPRM). Dana ini bagian dari program Hibah DPRM Tahun 2020. Program ini juga bekerja sama dengan pemerintah Desa Maitara Tengah, tempat pelaksanaan PKM di Aula Desa Maitara Tengah. Dengan begitu, kegiatan ini dapat memberikan kontribusi terhadap pengeloaan potensi Ekowisata yang ada di Desa Maitara Tengah.

\section{DAFTAR PUSTAKA}

Abdullah, 2016. Analisis Pengembangan Potensi Obyek Wisata Tepian Pantai Kota Tidore Kepulauan, Universitas 45 Makassar

Damanik \& Weber, 2006. Perencanaan Ekowisata. Pusat Studi Pariwisata PT. Andi Yogyakarta.

Haerani, H. (2012). Pengembangan kawasan ekowisata di pulau maitara kota tidore kepulauan. I(Ekowisata), 39-46.

Hanafi, H.-S. (2011). Model Pengembangan Ekowisata dalam Upaya Pemberdayaan Masyarakat Lokal. Politik Indonesia, 1(95), 117-151.

Pratama, R. (2020). Pengantar Manajemen. Deepublish.

Pratama, R. (2019). Pengaruh Modal, Lokasi Dan Jenis Dagangan Terhadap Pendapatan Pedagang Pasar. Jurnal Mitra Manajemen, 
449 Pengembangan Ekowisata dalam Upaya Pemberdayaan Masyarakat Lokal di Desa Maitara Tengah Kecamatan Tidore Utara - Yetty, Rheza Pratama, Johan Fahri

DOI : https://doi.org/10.31004/abdidas.v1i5.98

2(4), 273 285.http://ejurnalmitramanajemen

.com/index.php/jmm/article/view/125/69 